\title{
Success and Mobility of Generation Y: A Comparative Study on the Example of Poland And Austria
}

\author{
Izabela Bednarska-Wnuk (Ph.D.) \\ Katarzyna Januszkiewicz (Ph.D.)
}

Faculty of Management, University of Lodz ul. Matejki 22/26, Poland

\section{Doi:10.5901/mjss.2013.v4n9p410}

\begin{abstract}
Today, the paradigm of career undergoes significant transformations. Increasing globalization, concerning the availability of design and arbitrariness of their compilation, led to the question of differences in the perception of career success, the value bound with it and mobility, depending on the country in which the individual lives. In this article, the basis of the analysis are studies conducted in Poland and Austria, countries with different macroeconomic, historical and society conditions. The results prompted the observation that the global exchange of professional development is universal, but also very general. Representatives of the Generation Y from Poland and Austria are different because of the specific characteristics of their professional careers, including the values which characterize professional success, a willingness to conduct mobile behaviour and undertaken activities
\end{abstract}

Keywords: professional success, job mobility, generation Y, Poland, Austria

\section{Introduction}

Due to the increasing complexity and volatility of the environment and increasing mobility of workforce, the competence of potential employees plays increasingly important part in the analysis of human capital. Today in Europe there is a high proportion of young people, representing Generation $Y$, and at the same time, this is the generation most affected by the global crisis. It is, therefore, worth looking at what their professional attitude towards change. Some of them is a natural result of socio-demographic changes in the organization area and promotion of mobility as a natural activity present in society, and others are the result of environmental factors. It is therefore important to diagnose the source of these attitudes and to ask whether they are focused on the mobile and success behavior, and if so, how will generation $Y$ define these actions.

The purpose of this article is to identify the understanding of job mobility and career success in the generation $\mathrm{Y}$. This paper will present the results of research conducted in Poland and Austria, among the elected representatives of the generation $\mathrm{Y}$. The choice of countries was purposeful, because of the various macroeconomic conditions.

\section{Socio-economic conditions in Poland and Austria}

Ongoing socio-demographic changes have an impact on the economic situation of many countries. In addition, unfavorable macroeconomic phenomena, such as unemployment, low economic growth, rising interest rates, inflation causes unfavourable changes in professional attitudes. Except that, the global economic crisis on the financial markets and banking started in 2007 in the United States, made the economies of many countries, including those European countries (Spain, Portugal or Greece) were on the brink of bankruptcy. Also a country like Austria, which until then used the good times, with a favorable geographical location and close ties with Germany and the countries of Central and Eastern Europe, was forced to deal with the negative effects of the crisis.

The Austrian economy, characterized by a medium-term sustainable growth (average GDP growth in 1997-2007was 2.5\%), in 2009 entered a recession. A significant decrease in interest for export, mainly from Germany (the main trading partner of Austria) effectively limited the opportunities to create added value in the economy (decline in exports in 2009 amounted to 16.1\%). Negative trends that are closely linked to the reduction of the supply of goods and services became very quickly apparent to the other planes of the real economy. While the increase in unemployment in 2009 was 
not a big problem, a limited supply of money was reflected in a very low, non-listed during the last decade level of inflation. The situation appears to be stabilizing thanks to strong impulse on the part of the return to good health of the German economy through the introduction of anti-crisis plan, including the ongoing reconstruction and domestic investment (Ministry of Economy, Department of Analyses and Forecasting, p.8.). Currently, although the Austrian economy is growing more slowly than before the crisis, as the European Commission figures show the rate of inflation for 2012 was 2.6\%, real GDP growth only $0.6 \%$ and unemployment at the end of April 2013 stood at only $4.9 \%$ (Eurostat, http://epp.eurostat.ec.europa.eu). Optimistic is the fact that unemployment among young people under 25 years is $8 \%$, compared to the same period in Portugal (42.5\%) and Spain (56.4\%), which suggests a very good employment policy in Austria despite the economic downturn.

Slightly different is the situation on the labor market in Poland, the only one that in the face of the global crisis in 2009 reported positive real growth rate 1.6\% (Sternad 2012, s.257). It should be noted that Polish economic situation before joining the European Union in 2004 has been dramatic. For example, real GDP growth in Poland in 2002 wynosiło $1.4 \%$, inflation $1.9 \%$ and unemployment $20 \%$. The specific situation could be seen among young people of whom up to $42.5 \%$ were unemployed (Eurostat, http:// epp.eurostat.ec.europa.eu). Adverse events in Poland were gradually eliminated from the moment of its accession to the European Union. This was mainly due to start-up of investments co-financed from EU structural funds (Knapińska 2012, p 153). In addition to the investments made in Poland related to the upcoming Euro 2012 affected the economic situation of the country. Today, however, although the end of 2012 amounted to 1.9\% of GDP (more than in Austria) and inflation - (3.7) unfortunately, unemployment at the end of April was up 10.8\%, as compared to Austria - it is almost twice as high, but much lower than for example in Spain, Portugal, Greece, Slovakia or Cyprus. For quite some time, Poland has faced a similar problem as the states of the southern European countries, namely rising unemployment among young people. Currently (end April 2013) it is 27.6\% (Eurostat, http://appsso.eurostat.ec.europa.eu/nui/submitViewTableAction.do).

Thus comparing the macroeconomic data presented above in both countries, it should be noted that the Austrian economy is characterized by a higher economic level than Poland. Synthetically they have been presented in the table below.

Table 1. Macroeconomic of Poland and Austria

\begin{tabular}{|c|c|c|}
\hline Macroeconomic indicator & Poland & Austria \\
\hline Harmonised unemployment rate - (IV 2013) & $10.8 \%$ & $4.9 \%$ \\
\hline Harmonised unemployment rate- less than 25 years - IV 2013 & $27.6 \%$ & $8 . \%$ \\
\hline Employment growth rates (I quarter 2013) & $-0.6 \%$ & $0.8 \%$ \\
\hline HICP - inflation rate. Annual average rate of change (\%) - 2012 & $3.7 \%$ & $2.6 \%$ \\
\hline Real GDP growth rate - volume 2012. (Percentage change on previous year) & $1.9 \%$ & $0.8 \%$ \\
\hline
\end{tabular}

Source: Case study based on http://epp.eurostat.ec.europa.eu of 15 June 2013

Taking into account the selected socio-economic conditions in Austria and Poland, should considered whether they have an impact on the attitudes of young people towards professional work, in particular those who are just entering or will enter such asymmetric labor market. This is due to the deterioration of the situation on the European labor market for young people (Chung, Bekker, Houwing 2012). This is a pretty important issue, because it is how they will work will provide their future social and material status.

\section{Determinants of perceiving career of Gen $Y$}

The paradigm of career in the twenty-first century goes through an important transformation. Changes in the scope of functioning of modern organizations and the perception of professional development by the entity cause, that you can now talk more about the many coexisting concepts of career than one clearly defined and formalized career path (Bohdziewicz 2008).

Generation $Y$ is therefore launching its activities in a very specific reality. The paradigm of career values associated with it, and finally the idea of career success have been built so far based on the available scripts and were formed on the basis of the mechanism of introjection of certain value. In a period of relative stagnation, cultural and limited social mobility, standards for the entity determinant of behavior, were continuous and predictable. It marked the 
society, culture, the family in which she grew up. Changes were of evolution, not revolution. The next generation worked a legacy that were fostered and cherished. While the earlier group had a comfort of referring to already formed cognitive ${ }^{1}$ patterns, to predict what to expect in equal situations, Generation $Y$ is characterized by the uniqueness of the experience. In this particular period for the development and shaping of personality, which constitutes a vision of what one wants to achieve, both in private and professional life. Here and now new categories of social roles and the script for their implementation are created. It seems important for the context of the perception of career success, which is what an individual wants to achieve through work (Januszkiewicz, 2008).

The very notion of success is sometimes defined differently, and what goes with it, is it assigned different values. In addition, depending on the context evaluation, success can be seen in two areas: social norms - what has been recognized by the public as important, relevant and challenging and the ability of the entity - to what extent, the task proves to be such for her. With the development of the entity, these planes, to varying degrees, mark the direction of development. Moreover, in the era of extended and dynamic communication, an additional factor in determining the destination to which the individual is seeking is a global world, in which an entity assesses its local activities.

Another determinant of contemporary career is mobility. Increasingly, the literature reference is made to construct a mobile career, which results from changes in the nature of work, occupations, and finally the organization (Feldman, $\mathrm{Ng}$ 2007, p.351). Also, the implementation of a career without borders makes it essential characteristics, among others, individual mobility beyond the boundaries of organizations and individual employers and overcoming the limits of its other traditional careers (Arthur Rousseau, 1996, p.3 for Bohdziewicz 2008, p 158). Therefore important related issues to take actions by the entity to the mobile behavior (Bednarska-Wnuk 2013). While analyzing the concept of mobility in context it should be noted, that it is possible to extract the two ranges of meaning: labor mobility (the tendency to change the profession / professional qualifications) and spatial mobility (willingness to work in another location such as city, region or country). It is a simplified classification, because in the literature there are different divisions, based on different classifications (Sorokin, 2009, Szacka 2003, Nicholson, West 1988). However, the above example the division is important from the standpoint of the study of professional attitudes of individuals and diagnosis of their employment attractiveness. This article focuses on the issue of change of residence on taking or seeking employment elsewhere.

Increasing globalization, concerned on the availability of design and building their arbitrariness makes it worthwhile to ask the question: are there differences in the perception of career success, the value of the bound and mobility, depending on the country in which they live and whether the entity associated with the different macroeconomic conditions influence the actions seen as increasing the chances of success and made by the representatives of the generation $Y$.

\section{Research Methods}

The study involved 190 respondents in 2012, who were students of the two countries: Poland (109 people) and Austria (81 people). The tests were carried out respectively in Poland at Lodz University (Faculty of Management) and Austria on the University of Vien - Fakultät für Wirtschaftswissenschaften. The group was homogeneous in terms of level of study Bachelor's degree. Tests were anonymous and were carried out during classes by copyright questionnaire of perception of success and mobility2. The aim of this study was to identify the understanding of job mobility and career success in the generation $Y$ that make up the structure of the behavior in the field:

- Determining the degree of acceptance of the tendency of young people to professional and spatial mobility,

- Specifying the relationship of success of job mobility among young people,

- The characteristics of professional success in the context of professional value,

- Identifying the types of professional activity related to the perception of success

- Capturing the differences between the two research groups (Poland and Austria) in the perception of the determinants of success, spatial and professional mobility.

Since sampling was purposeful and does not meet the statistical requirements of representativeness, the obtained material only allows presenting opinion on the success and mobility in the perception of some young people from Poland

\footnotetext{
${ }^{1}$ In this study, cognitive schema is defined as a set of interrelated concepts, which is a general framework for thinking about a topic, event, object, person or situation in the life of the entity. See: P. G. Zimbardo, R. L. Johnson, V. McCann, Psychology of key concepts. Man and his environment, PWN, Warszawa 2010, p 34

${ }^{2}$ The study was conducted within the project "Individual and organizational determinants of labor mobility" No. 545/319 (2012) - Project Manager - Izabela Bednarska-Wnuk, Ph.D., and the "Success in the perception of future managers. A comparative study "No. 545/318 (2012) - Project Manager - Katarzyna Januszkiewicz, Ph.D.
} 
and Austria. Also included conclusions focus on the success and mobility of respondents and still do not go beyond the status of a hypothesis, but it is probable by the results of research.

\subsection{Analysis Results}

The first table shows the degree of acceptance of the tendency of respondents (Poland and Austria) to spatial mobility.

Table 2. Selected aspects of spatial mobility in the perception of Generation Y (\%)

\begin{tabular}{|l|c|c|c|c|c|c|c|c|c|c|}
\hline \multirow{2}{*}{ Statement } & \multicolumn{2}{|c|}{$\begin{array}{c}\text { Definitely } \\
\text { yes }\end{array}$} & \multicolumn{2}{c|}{ Rather yes } & \multicolumn{2}{c|}{ No opinion } & \multicolumn{2}{c|}{ Rather no } & \multicolumn{2}{c|}{ Definitely no } \\
\cline { 2 - 22 } & PO & AT & PO & AT & PO & AT & PO & AT & PO & AT \\
\hline Tendency to seek job in another town & 27.5 & 30.9 & 39.5 & 25.9 & 9.2 & 23.5 & 18.3 & 14.8 & 5.5 & 4.9 \\
\hline Tendency to seek job in another country & 22.9 & 34.6 & 27.5 & 32.2 & 12 & 16.1 & 25.6 & 12.3 & 12 & 4.9 \\
\hline Tendency to seek job in another continent & 19.3 & 33.3 & 18.4 & 23.5 & 7.3 & 19.8 & 26.6 & 4.9 & 28.4 & 18.5 \\
\hline
\end{tabular}

PO - Poland AT - Austria

Source: own study based on the results of their own research

The responses indicate that young Austrians are more likely to look for work in another country and continent than young Poles who in these respects are less likely to exhibit spatial mobility. Young Poles are often more mobile than young Austrians in the tendency to seek work, with a view to closer, in another city. However, it should be noted that the responses "probably not" or "definitely not" also occur in young Poles and their sum (21.2) is much higher than in other communities.

The next chart shows the tendency of the surveyed respondents for retraining / changing profession.

Figure 1: The tendency of respondents to retraining / changing profession (\%)

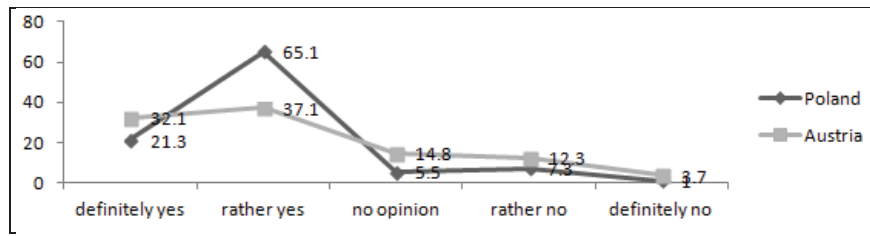

Source: own study based on the results of their own research

The responses indicate that both groups were most likely to change their professional qualifications, whilst young Poles are in this respect much more mobile than young Austrians (respectively 286.40 Poles and Austrians 569.20 ).

The next graph relates surveyed respondents about identifying the success of frequent retraining / changing profession (Figure 2). The results show that young Poles are more averse to that opinion. Most of them do not equate success with frequent change of profession. Although such answers young Austriana also reveal, however, there are also some positives. Interesting is the fact that in both groups, there is high rate of response - I have no opinion.

Figure 2. Identifying success with frequent retraining / changing profession (\%)

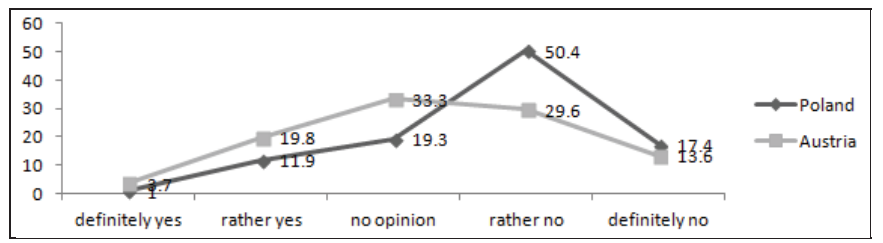

Source: own study based on the results of their own research 
Table 3 presents the results of research on other activity which in the opinion of respondents increased chance of achieving success (.....) and the activities they undertake (.....).

Table 3: Activities connected with achieving success

\begin{tabular}{|c|c|c|c|c|c|c|c|c|c|}
\hline & \multicolumn{4}{|c|}{$\begin{array}{l}\text { Poland } \\
N=109\end{array}$} & \multicolumn{4}{|c|}{$\begin{array}{l}\text { Austria } \\
\mathrm{N}=81\end{array}$} \\
\hline & & \multicolumn{2}{|c|}{ Wanted } & \multicolumn{2}{|c|}{ Realised } & \multicolumn{2}{|c|}{ Wanted } & \multicolumn{2}{|c|}{ Realised } \\
\hline & & $\mathrm{n}$ & $\%$ & $\mathrm{n}$ & $\%$ & $\mathrm{n}$ & $\%$ & $\mathrm{n}$ & $\%$ \\
\hline 1 & Learning a foreign language & 92 & 84.40 & 47 & 43.12 & 52 & 64.20 & 31 & 38.27 \\
\hline 2 & Visits to foreign countries & 63 & 57.80 & 13 & 11.93 & 42 & 51.85 & 20 & 24.69 \\
\hline 3 & Traineeships & 84 & 77.06 & 44 & 40.37 & 42 & 51.85 & 38 & 46.91 \\
\hline 4 & Establishing contacts & 74 & 67.89 & 37 & 33.94 & 64 & 79.01 & 23 & 28.40 \\
\hline 5 & Activity on Internet fora & 10 & 9.17 & 14 & 12.84 & 23 & 28.40 & 29 & 35.80 \\
\hline 6 & Trainings and exercises & 72 & 66.06 & 37 & 33.94 & 45 & 55.55 & 27 & 33.33 \\
\hline 7 & Participation in lectures & 23 & 21.10 & 9 & 8.26 & 34 & 41.97 & 34 & 41.97 \\
\hline 8 & Reading of specialist press & 40 & 36.70 & 30 & 27.52 & 37 & 45.68 & 39 & 48.15 \\
\hline 9 & Higher studies & 75 & 68.81 & 89 & 81.65 & 61 & 75.31 & 22 & 27.16 \\
\hline
\end{tabular}

Source: own study based on the results of their own research

Our research results indicate that in the opinion of Poles, language learning is the most desired activity on the way to success (84.40\%). Further high indications are however, linked to professional development (job placement - 77.06\%, higher education - 68.81\%; professional networking - 67.89\%; training and workouts - 66.06\%). For Generation $Y$ representatives from Austria, the most important for success is to study (75.31\%) as well as for the Poles, but to a lesser extent - the study of foreign languages (64.20\%). It is worth noting that in both groups, as the least increasing the chance of success was activity in professional forums (Polish - 9.17\%, Austria - 28.40\%).

You can also see differences in the activities undertaken by the respondents. In the group of Poles, many people pointed to the study, as the activity carried out with a view to future success (81.65\%), while in the group of Austrians most commonly taken activities were reading of skilled labor (....), and job placement. A graphical display of the degree of consistency in the activities referred to as improving the chances of success and the activities carried out by the treatment groups are shown in Figure 3

Figure 3: Activities related to professional success
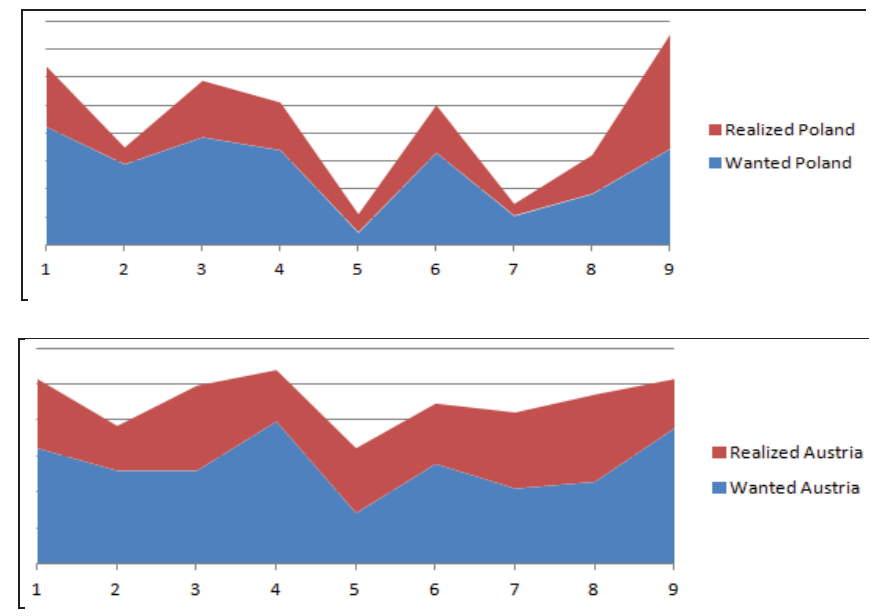

Source: own study based on the results of their own research 
In the group of Poles, most people pointed to the study as the activity is carried out with a view to future success $(81.65 \%)$, while in the group of Austrians most commonly activities were reading of skilled labor (....), and job placement. Another of the areas researched was the extent of introjection of professional values in the perception of success. The obtained results are presented in Table 4.

Table 4. Value in the perception of career success

\begin{tabular}{|c|c|c|c|c|c|}
\hline & \multicolumn{2}{|c|}{$\begin{array}{l}\text { Poland } \\
\mathrm{N}=109\end{array}$} & \multicolumn{2}{|c|}{$\begin{array}{c}\text { Austria } \\
\mathrm{N}=81\end{array}$} \\
\hline & & $\mathrm{n}$ & $\%$ & $\mathrm{n}$ & $\%$ \\
\hline \multicolumn{6}{|c|}{ Power } \\
\hline 1. & Having power & 23 & 21.10 & 20 & 24.69 \\
\hline 2. & Achieving social prestige (titles) & 36 & 33.03 & 27 & 33.33 \\
\hline 3. & Exerting some impact on other people & 37 & 33.94 & 20 & 24.69 \\
\hline 4. & Controlling one's environment & 15 & 13.76 & 14 & 17.28 \\
\hline 5. & Respect and prestige & 82 & 75.23 & 37 & 45.68 \\
\hline \multicolumn{6}{|c|}{ Achievements } \\
\hline 6. & Reaching higher and higher standards of performing & 44 & 40.37 & 17 & 20.90 \\
\hline 7. & Taking up the tasks perceived as a challenge & 42 & 38.53 & 34 & 41.98 \\
\hline 8. & Continuous improvements at work & 70 & 64.22 & 43 & 53.09 \\
\hline \multicolumn{6}{|c|}{ Afiliation } \\
\hline 9. & Spending time with other people & 10 & 9.17 & 29 & 35.80 \\
\hline & Establishing and maintaining good relationships & 33 & 30.28 & 15 & 18.52 \\
\hline & Helping other people & 12 & 11.01 & 14 & 17.28 \\
\hline \multicolumn{6}{|c|}{ External attributes } \\
\hline 12. & Specific style of getting dressed (expensive, designer) & 8 & 7.34 & 7 & 8.64 \\
\hline 13. & Having good and items (expensive car, house etc.) & 11 & 10.09 & 17 & 20.99 \\
\hline
\end{tabular}

Source: own study based on the results of their own research

The results indicate that the perception of respondents success is connected to the greatest extent with the values attributed to the realm of performance (including in particular the "continuous improvement at work" - $64.22 \% 53.09 \%$ Poles and Austrians found this to be an important area) and the sphere of power (including the highest score recorded for the sense of "respect and prestige" - $75.23 \%$ and $45.68 \%$ Poles, Austrians found this to be an important area). In the area of affiliation, the most important in the perception of success turned out to be such characteristics as "spending time with other people" and "Establishing and Maintaining good relationships." Nonetheless, there were differences between the groups in the weight of individual items. For the Poles, by far the most successful is associated with a sense of prestige and respect, but for the Austrians - improvement in the performance of tasks.

\subsection{Discussion of Results}

Representatives of Generation Y pursuing a career are facing difficult choices. The ambiguity of paradigm is that success can be achieved in many ways. According to the Polish people the opportunity to achieve career goals is mostly increased by: language learning and job placement. Also highly rated were trips abroad (study or internships). These results might suggest that they are aware of the importance of gaining experience at international level in the perspective of professional development. However, this knowledge does not translate into actions taken by them. This is confirmed by the results for the acceptance of a tendency to spatial mobility discussed in further part of work.

With respect to the group of Austrians it should be noted that in their opinion the greatest chances of success are increased by networking and professional study. These results may indicate the respondents believe in the importance of social capital and informal relationships. In this group the most usually taken activities are actions related to improvement of professional qualifications, which proves the conviction of the importance of external factors, but in the action taken internal control placement.

In the context of the perception of career success, presented findings prompted the observation that the representatives of Gen $Y$ from Poland as well as from Austria, this category is combined with similar values. Nonetheless, there were minor differences, which, although not entitled to draw conclusions, allow you to indicate 
whether there are different trends in the evaluation of job performance.

For Poles, success means prestige and social respect (75.23\%). These results may indicate a tendency for the compilation of job performance with an external criterion - what others consider to be important and desirable. Among the Austrians, this value also gained high marks (45.58\%), but most responses related to continuous improvement in the workplace $(53.09 \%$ in the group of Poles $64.22 \%)$, which in turn can be interpreted as a manifestation of internal orientation - raising their qualifications and achieve ever higher level tasks. That interpretation is confirmed by the results of previous studies related to activities carried out by the respondents in order to achieve career success.

Both groups relatively little connect the success with the implementation of the affiliation sphere. Success in the perception of Gen $Y$ is therefore a category assessed from the individualistic perspective - its achievement means a greater focus on "me" rather than building relationships with others (that also confirms the relatively high score for "influencing others" - Poland 33.95\%; Austria 24.69\%).

Taking the results of empirical research on the perception of spatial mobility into account, it can be seen that the young Austrians are in fact more mobile (another country, continent) than young Poles. This is probably due to cultural and professional habits of Polish generation and the previous economic system (socialism), in which the first job was also the last. Furthermore, there was the ease in finding work, giving a sense of security and stability. Although the young Poles have a tendency to migrate to another city or country, it would have a place only within the borders of the European Union, preferably close to the country of their residence. Regarding work in another continent is in this respect they exhibit lesser tendency than young Austrians (unlikely - and certainly not 26.6 28.4). It is quite surprising, because although Austria has low unemployment, professional attitude of young Austrians tend to be highly flexible.

Interesting is the fact that both young Poles and Austrians are willing to change their professional qualifications I profession, although the first group received significantly higher affirmative values (respectively 286.40 Poles, Austrians [69.20). Both groups are therefore mostly aware that today it is not enough to settle their education after university, but they must constantly develop through participation in various forms of professional development. Also studied community - young people, because they usually only study or work part-time, are not as strongly attached to the employer and to the learned profession than the older generation. That is why they are in fact more likely to change jobs than, eg: their counterparts in the past century. It is encouraging especially in the context of the dynamic and unpredictable job market. This tendency does not mean, however, in the case of the respondents that identified it with achieving professional success. However, they may provide an increase in awareness of the importance of intentional self-development and career growth of the responsibility for the future professional life. An interesting aspect of the responses, however, are positive answers obtained. Perhaps (though a minority), some young people feel that in order to achieve professional success it is constantly changing guidance and make its review. In view of the foregoing, while on the propensity to change their professional qualifications / profession and current on achieving success it is necessary to separate the two issues. First, the tendency to re-training with the idea of learning throughout life and means an increase of awareness among individuals, in order to find their place on asymmetric labor market, they need to improve or change their own professional skills. Secondly, it should not be made only with the idea that it reaches a successful career. Indeed, these two areas tend to change jobs and achieve success by an entity and should be two overlapping homogeneous regions, and should not be treated as just complementary elements. This is particularly important especially in the context of the transfer of responsibility to construct their own career scheme.

\section{Summary}

The analysis of the literature and the results of own research conducted in this paper made it possible to draw a number of synthetic conclusions that constitute the answer to the research questions at the outset. The considerations lead to the observation that the global exchange of professional development is universal, but also very general.

Representatives of the Gen $Y$ from Poland and Austria seem to differ because of the specific characteristics of their professional careers. It should be noted that the generation $\mathrm{Y}$, identified through the prism of uniformity and egalitarianism in access to resources offered by a global network, remains heterogeneous in the scope of actions and ways to pursue their careers. A different way of defining success, the value of it, connects with varying degrees of acceptance of mobile behaviors in the career. It is difficult, of course, on the basis of the presented trial, to clearly determine whether it is related to macroeconomic conditions, whether it is a derivative of the socio-cultural factors - it is an issue that requires the in-depth interdisciplinary analysis and expanding research area to other countries. 


\section{References}

Bednarska-Wnuk I. (2013). Zachowania mobilne pracownika w miejscu pracy - próba identyfikacji kluczowych determinant, Acta Universitatis Lodziensis Folia Oeconomica, in print.

Bohdziewicz P. (2008). Kariery zawodowe w gospodarce opartej na wiedzy (na przykładzie grupy zawodowej informatyków), Wydawnictwo. Uniwersytetu Łódzkiego, Łódź.

Chung H., Bekker S., Houwing H. (2012). Young people and the post-recession labour market in the context of Europe 2020, Transfer: European Review of Labour and Research, Vol.18, No.3, pp. 299-315.

http://epp.eurostat.ec.europa.eu/tgm/table.do?tab=table\&init=1\&language=en\&pcode=tsdec460\&plugin=1 Available 10 June 2013

http://jom.sagepub.com/content/33/3/350, Available 12 June 2013.

Feldman D. C., Ng T.W.H. (2007). Careers: Mobility, Embeddedness, and Success, Journal of Management Vo.33, No.3.

Januszkiewicz K. (2009). Rozwój zawodowy pracownika. Szanse i zagrożenia. Wydawnictwo Uniwersytetu Łódzkiego, Łódź.

Knapińska M. (2012). Wspólny europejski rynek pracy. Geneza-rozwój-funkcjonowanie, Wydawnictwo Uniwersytetu Ekonomicznego w Poznaniu, Poznań.

Ministerstwo Gospodarki, Departament Analiz i Prognoz, Koniunktura gospodarcza w wybranych krajach w okresie kryzysu finansowego, Warszawa Styczeń 2011, [Online] Available http://www.mg.gov.pl/files/upload/8441/MG_DAP_Koniunktura_gosp. _w_wybranych_krajach_w_okresie_kryzysu\%20_fin.pdf.

Nicholson N , West M. (1988). Managerial Job Change: Men and Women in Transition, Cambridge University Press.

Sorokin P. (2009). Ruchliwość społeczna, Wydawnictwo Instytutu Filozofii i Socjologii PAN, Warszawa 2009.

Sternad D. (2012). Adaptive Strategies in Response to the Economic Crisis: A Cross-Cultural Study in Austria and Slovenia, Managing Global Transitions, International Research Journal, Fall, Vol. 10 Issue 3, pp.257-282.

Szacka B. (2003). Wprowadzenie do socjologii, Oficyna Naukowa, Warszawa 2003. 